\title{
Spatial Distribution of Weed Seed Banks in the Agricultural Field and Anthropized Cerrado
}

\author{
Klayton Antonio do Lago Lopes (Corresponding author)
}

Federal University of Maranhão, Center for Agricultural Sciences and Environmental

Chapadinha, Maranhão, Brazil

E-mail: klaytonlopes2011@gmail.com

Marcelo de Sousa da Silva

Federal University of Maranhão, Center for Agricultural Sciences and Environmental

Chapadinha, Maranhão, Brazil

E-mail: marcelosousamj@hotmail.com

Leandro dos Santos Costa

Federal University of Maranhão, Center for Agricultural Sciences and Environmental

Chapadinha, Maranhão, Brazil

E-mail: santleandrocosta@gmail.com

Taciella Fernandes Silva

Federal University of Maranhão, Center for Agricultural Sciences and Environmental

Chapadinha, Maranhão, Brazil

E-mail: taciellafernands@gmail.com

Tiago Vieira da Costa

Federal University of Maranhão, Center for Agricultural Sciences and Environmental

Chapadinha, Maranhão, Brazil

E-mail: tiagosly@hotmail.com 
Edmilson Igor Bernardo Almeida

Federal University of Maranhão, Center for Agricultural Sciences and Environmental Chapadinha, Maranhão, Brazil

E-mail: edmilson_i@hotmail.com

Ismênia Ribeiro de Oliveira

Federal University of Maranhão, Center for Agricultural Sciences and Environmental

Chapadinha, Maranhão, Brazil

E-mail: ismenia.ribeiro.oliveira@gmail.com

José Roberto Brito Freitas

Federal University of Maranhão, Center for Agricultural Sciences and Environmental Chapadinha, Maranhão, Brazil

E-mail: joserobertobritofreitas@yahoo.com

Washington da Silva Sousa

Federal University of Maranhão, Center for Agricultural Sciences and Environmental

Chapadinha, Maranhão, Brazil

E-mail:wssousa@gmail.com

Leonardo Bernardes Taverny de Oliveira

Federal University of Maranhão, Center for Agricultural Sciences and Environmental Chapadinha, Maranhão, Brazil

E-mail: tavernyzoot@yahoo.com

Received: Dec. 15, 2019

doi:10.5296/jas.v8i2.16031
Accepted: Mar. 24, 2020 Published: Mar. 26, 2020

URL: https://doi.org/10.5296/jas.v8i2.16031 


\section{Abstract}

Characterization of the seeds bank is an essential tool for decision making on weed control and management practices and the study and maintenance of the ecological dynamics of natural areas. In this context, the present study aimed to characterize the spatial variability of the seeds bank in an experimental agricultural field and an anthropized cerrado area, using the ordinary kriging geostatistical technique. Sampling was carried out on 10x10 regular grids in two different environments. Area 01 consisted of an experimental agricultural field of annual crops (soy and corn); area 02 represented the anthropized cerrado. The sample grids consisted of 25 points collected at a depth of $0.00-0.20 \mathrm{~m}$. The soil samples were placed in $6.38 \mathrm{dm}^{3}$ and $0.05 \mathrm{~m}^{2}$ plastic containers. Spatial distribution maps of the species found have been drawn up, grouped in dicotyledonous, monocotyledonous, and total density, in addition, the density of three weeds most found in each area. The weed seed bank present strong spatial variability to 01 and 02 , which indicates behavior in spots or in patches for both dicotyledonous and monocotyledonous plants, especially Mollugo verticillata L. and Eleusine indica (L.) Gaertn. in the experimental field, and for Richardia scabra L. and Eleusine indica (L.) Gaertn. in the anthropized cerrado. The ordinary kriging technique made it possible to map the weed seed bank and, therefore, it may work as an efficient tool in controlling weeds in agricultural fields, especially in its pre-emergence phase. Furthermore, it can assist in the recovery of native anthropized vegetation.

Keywords: dicotyledonous, geostatistics, kriging, monocotyledonous, precision agriculture

\section{Introduction}

Weeds are constantly adapted to disturbed environments, mainly due to linked factors into seed such as high yield, efficient dispersion, longevity, and especially dormancy. These characteristics facilitate the formation of extensive seed banks in the soil, which enables the regenerative capacity of several species, even in the absence of long-term seed production, making them the main obstacle to weed control (Silva et al., 2014).

The size and botanical composition of the propagule population in the soil are characterized by dynamic behavior, it results, at a given moment, from the balance between inputs (production and dispersion) and system losses due to predation, deterioration, parasitism, allelopathy, germination, and transport. (Silva et al., 2014; Amim et al., 2016).

The study about the composition and density of the seed bank is of great importance to understand the ecological dynamics of natural areas and assist in the species conservation with relevant ecological interest to promote natural regeneration of disturbed environments. (Leal Filho et al., 2013). Besides, it can be considered an important tool for weeds management in agricultural areas, which can cause between 30 and $40 \%$ of the average falls on productivity (Franco et al., 2012).

Seed bank characterization is an important decision-making tool for control practices and weed management (Monquero and Christoffoleti, 2005). The main purpose of any weed management system is to modify the environment in a way to prevent the development of the weed community through the specific or combined use of different control practices to reduce 
weed populations (Ferreira et al., 2013). In this sense, a prior and accurate analysis of the weed seed bank would enable more effective planning and control of the infestation, as well as the most appropriate application of pre-emergent herbicides (Cardina and Sparrow, 1996).

Thus, precision agriculture tools can be used for specific management applications only at the desired location because of weeds develop in aggregate form and require prior target mapping. (Baio et al., 2013). In this way, data collection and also infestation maps help in the management of the best control methodology of the species present in the area (Christensen et al., 2011), aside to the reduction in herbicide costs and environmental impacts caused by the irrational use of these products (Baio et al., 2013).

Through geostatistics, it is possible to evaluate the spatial dependence and use the spatial correlation between the data to interpolate values in non-sampled locations. This information enables to design continuous maps from careful sampling (Vieira, 2000). Therefore, geostatistics allows technically to infer complex strategies in relation to management to be adopted, as well as environmental and productive effects (Grego et al., 2014).

Several authors have adopted geostatistics to study the spatial variability of weeds in the corn crop (Calha et al., 2014), soybeans crops (Santi et al., 2014), in the cultivation of grains and cover crops (Chiba et al., 2010) and sunflower crops (Siqueira et al., 2016). However, studies on the spatial distribution of the weed or invasive bank both in cultivation areas and in areas of native vegetation are scarce in the literature.

Therefore, this study aimed to characterize the spatial variability of the seed bank in an experimental agricultural field and in an anthropized cerrado area, using the ordinary kriging geostatistical method.

\section{Material and Methods}

The experiment was carried out in a shaded environment (25\% light interception), from January to April 2019, at the Centro de Ciências Agrárias e Ambientais (CCAA) of the Universidade Federal do Maranhão (UFMA), located in the municipality of Chapadinha, Maranhão state (MA), Brazil (0344'28.7' S; 4318'46” W and $107 \mathrm{~m}$ altitude). The climate in this region is classified by Köppen as Aw, warm and humid. Presenting annual mean precipitation of $1,613 \mathrm{~mm}$ and annual mean temperature of $27.9^{\circ} \mathrm{C}$ (Passos et al., 2016). 


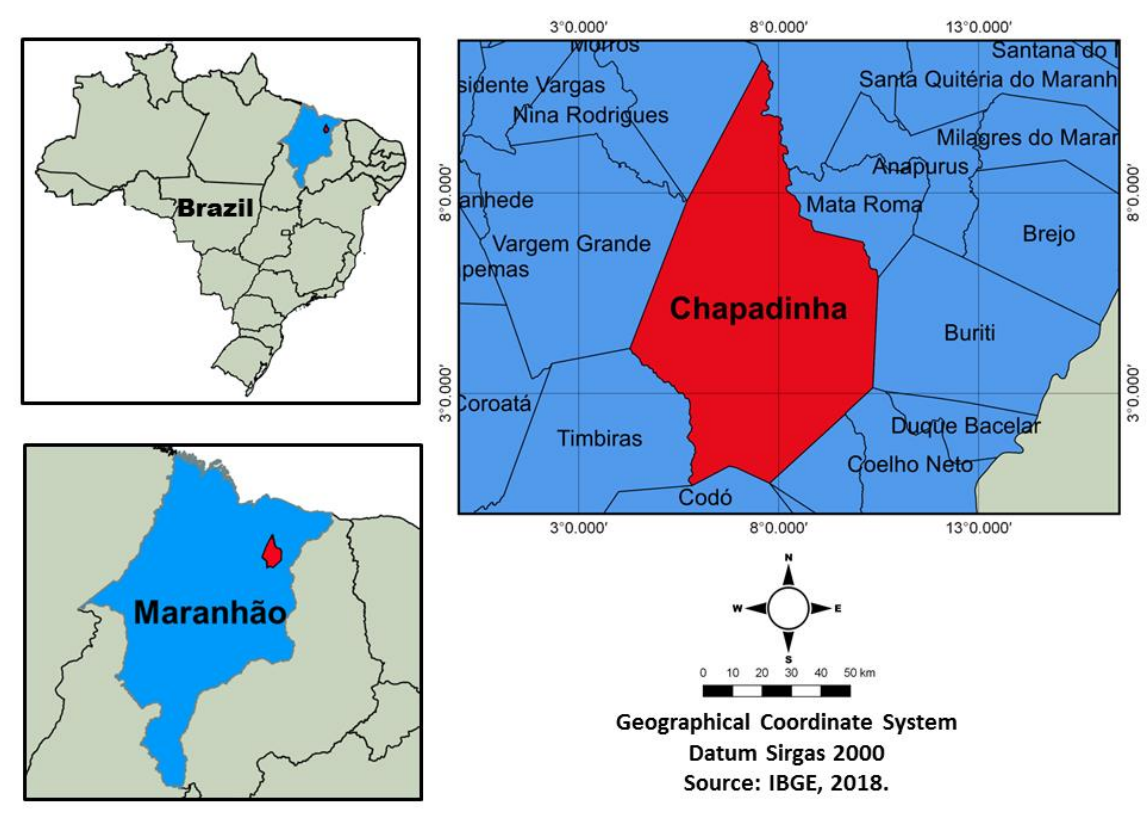

Figure 1. Location map of the municipality of Chapadinha (MA)

The sampling was carried out in regular $10 \times 10 \mathrm{~m}$ meshes in two areas with different environments from CCAA, UFMA. The first area (Area 01) consisted of an experimental agricultural field in fallow land, with soybean and corn cultivation history; the second area (Area 02) represented the anthropized cerrado. It is worth mentioning, in the second situation, the study considered the species of plants with the potential to become weeds to agricultural activity. Sampling grids consisted of 25 points each, with regular georeferenced distances. Each point referred to a composite sample consisting of three sub-samples, at a depth of $0.00-0.20 \mathrm{~m}$ of soil.

The characterization of the seed bank was carried out based on Monquero et al. (2008). Soil samples were placed in plastic containers of $6.38 \mathrm{dm}^{3}$ and $0.05 \mathrm{~m}^{2}$ of circumference area. Emergency flows were analyzed at 20, 40, 60, 80, 100, and 120 days. After each emergency flow, the plants were identified based on the specialized literature (Lorenzi, 2008), quantified and removed from the pot. When it was not possible to identify in the early stage, weeds were transplanted for later cultivation and identification. Quantification was expressed as seed density per area after the sum of emerged seedlings. At 60 days after the installation of the experiment, the soil was revolved to stimulate new emergency flows, as recommended by Monquero et al. (2008).

Through georeferenced sampling and the results obtained in the pots were made a density spatial distribution maps of the species found, grouped into dicotyledonous (DICO), monocotyledonous (MONO) and total density (DENS), besides density of three weeds most commonly found in each area. The aggregate character of the distribution was evaluated by the dispersion index (ID) $=\sigma^{2} / \mu$, which indicates the variance ratio $\left(\sigma^{2}\right)$ by the mean $(\mu)$ (Cardina et al., 1995; Shiratsuchi, 2005), where values larger than the unit show aggregate distribution. The $\mathrm{k}$ parameter of the negative binomial distribution was calculated by the 
moment method: $\mathrm{k}=\mu^{2} / \sigma^{2}-\mu$, in which, the mean $\mu$ and the sample variance $\sigma^{2}$, inversely related to the degree of aggregation, as used by Schaffrath et al. (2007).

The Sorensen Similarity Index (I.S.) was estimated to analyze the similarity of the species found in the weed seed bank in the two sampling environments. It was calculated by the following formula: I.S. = $(2 \mathrm{a} / \mathrm{b}) \times 100$, where " $a$ " is the number of common species in the sampled areas and "b" total number of species in the sampled areas (Ferreira et al., 2014; Jakelaitis et al., 2014; Lousada and Esteves, 2017).

The tendency, dispersion, and distribution of the number of weeds present in the seed bank were evaluated by descriptive statistics analysis (mean, median, standard deviation, coefficient of variation, maximum, and minimum values, kurtosis and asymmetry). To verify the hypothesis of data normality, the Kolmogorov-Smirnov test was used, at a 5\% probability level.

The spatial variability of the attributes was characterized by semivariogram, determined by the ratio between the variance and the separation distance, according to Equation 1:

$$
\hat{\gamma}(h)=\frac{1}{2 N(h)} \sum_{i=1}^{N(h)}\left[z\left(x_{i}\right)-z\left(x_{i}+h\right)\right]^{2}
$$

Where, $\hat{y}(h)$ is the experimental semivariance for a separation distance $h, z\left(x_{i}\right)$ is the property value at point $i$, and $N(h)$ is the number of pairs of points separated by distance $h$.

According to the mathematical model adjustment, the theoretical model parameters for the semivariogram were defined (nugget effect, $\mathrm{C}_{0}$; structural variance, $\mathrm{C}_{1}$; threshold, $\mathrm{C}_{0}+\mathrm{C}_{1}$; and range, $\mathrm{A}_{0}$ ). The choice of the semivariogram theoretical models and the adjustment of their parameters were made by observing the smallest sum of the squared deviations (SQD); the highest coefficient of determination $\left(\mathrm{R}^{2}\right)$, in which values of $\mathrm{R}^{2}$ closest to 1 characterize the most efficient model to express the studied phenomenon; and the highest degree of spatial dependence (GDE), estimated for each species or group.

The classification of the degree of spatial dependence (GDE) was based on the ratio between the nugget effect and the threshold $\left(\mathrm{C}_{0} / \mathrm{C}_{0}+\mathrm{C}_{1}\right)$. GDE ranges from strong (GDE $\left.\leq 25 \%\right)$; moderate, $(25 \%<\mathrm{GDE} \leq 75 \%)$; to weak (GDE $>75 \%)$ (Cambardella et al., 1994).

After modeling the semivariogram, the ordinary kriging technique (KO) was used to interpolate values in unsampled places (Soares, 2006). This technique is based on a weighted moving average of neighboring samples obtained by Equation 2.

$$
\hat{z}\left(x_{0}\right)=\sum_{i=1}^{N} \lambda_{i} z\left(x_{i}\right), \text { with, } \sum_{i=1}^{N} \lambda_{i}=1
$$

Where $\hat{z}\left(x_{0}\right)$, is the value estimated at point $0 ; N$ is the number of values used in the estimation; $\lambda$ is the weight associated with each observed value, and $\mathrm{e} z(x i)$ is the value observed at point $i$. The weights $\left(\lambda_{i}\right)$ of each neighbor were determined using the adjusted 
semivariogram model, resulting in an estimate of minimum variance (Soares, 2006).

Geostatistical modeling was performed using the GS + program, version 9 (Gamma Design Software, 2008). The Surfer program (Surfer, 1999) was used for the elaboration of the spatial distribution maps of the attributes.

\section{Results and Discussion}

Weed species found in the seed banks for the two sampled areas are shown in Tables 1 and 2. At area 01, 17 weed species belonging to 13 botanical families were identified. Among the families with the largest number of species, it highlights the Poaceae (three species), Asteraceae (two species) and Rubiaceae (two species) families.

Concerning the number of seedlings emerged in the seed bank, the most representative species were Mollugo verticillata L., Sida rhombifolia L. and Eleusine indica (L.) Gaertn. with $32.00 \%, 25.28 \%$ and $12.38 \%$, respectively (Table 1).

Table 1. Percentage of weed species emerged in the seed bank from the experimental agricultural field (area 01)

\begin{tabular}{|c|c|c|c|}
\hline Botanical Families & Scientific Name & Code & $(\%)$ \\
\hline \multicolumn{4}{|c|}{ Experimental agricultural field } \\
\hline Amaranthaceae & Alternanthera tenella Colla & ALRTE & 0.09 \\
\hline \multirow{3}{*}{ Asteraceae } & Emilia coccinea (Sims) G. Don & EMIFO & 2.36 \\
\hline & & & \\
\hline & Jaegeria hirta (Lag.) Less. & JAGHI & 0.03 \\
\hline Commelinaceae & Tradescantia fluminensis Vell. & TRAAL & 0.03 \\
\hline Cyperaceae & Cyperus iria $\mathrm{L}$. & CYPIR & 4.42 \\
\hline Euphorbiaceae & Chamaesyce prostrata (Aiton) Small. & EPHPT & 1.82 \\
\hline \multirow[t]{2}{*}{ Fabaceae-Mimosoideae } & Mimosa hirsutissima Mart. & Nonexistent & 0.24 \\
\hline & Coix lacryma-jobi L. & COXLJ & 0.54 \\
\hline \multirow[t]{2}{*}{ Poaceae } & Cenchrus echinatus L. & CCHEC & 4.75 \\
\hline & Eleusine indica (L.) Gaertn. & ELEIN & 12.38 \\
\hline Lamiaceae & Marsypianthes chamaedrys (Vahl) & $\mathrm{MAXCH}$ & 0.21 \\
\hline
\end{tabular}


Kuntze

$\begin{array}{cccc}\text { Malvaceae } & \text { Sida rhombifolia } \text { L. } & \text { SIDRH } & 25.28 \\ \text { Molluginaceae } & \text { Mollugo verticillata } \text { L. } & \text { MOLVE } & 32.00 \\ \text { Plantaginaceae } & \text { Scoparia ducis } \text { L. } & \text { SCFDU } & 9.02 \\ & \text { Richardia scabra } \text { L. } & \text { RCHSC } & 2.69 \\ \text { Rubiaceae } & \text { Spermacoce capitata } \text { Ruiz \& Pav. } & \text { BOICA } & 1.88 \\ & & & \\ \text { Turneraceae } & \text { Turnera } \text { subulata } \text { Sm. } & \text { TURUL } & 2.24\end{array}$

At area 02,13 species were identified, belonging to 10 botanical families. The families with the largest number of species were Poaceae and Euphorbiaceae with three and two species, respectively. Regarding the number of seedlings emerged in the seed bank, the most representative species were Richardia scabra L., Tradescantia fluminensis Vell. and Eleusine indica (L.) Gaertn., with $23.81 \%, 19.76 \%$ and $17.94 \%$, respectively (Table 2).

Table 2. Percentage of species emerged from the seed bank of the anthropized cerrado area (area 02)

\begin{tabular}{cccc}
\hline $\begin{array}{c}\text { Botanical } \\
\text { Families }\end{array}$ & Scientific Name & Code & (\%) \\
\hline & Anthropized cerrado & & \\
\hline Amaranthaceae & Alternanthera tenella Colla & ALRTE & 10.71 \\
Commelinaceae & Tradescantia fluminensis Vell. & TRAAL & 19.76 \\
Cyperaceae & Cyperus iria L. & CYPIR & 13.02 \\
Euphorbiaceae & Dalechampia scandens L. & Nonexistent & 0.79 \\
& Chamaesyce prostrata (Aiton) Small. & EPHPT & 4.29 \\
Malvaceae & Sida rhombifolia L. & SIDRH & 2.70 \\
Plantaginaceae & Scoparia ducis L. & SCFDU & 0.56 \\
Poaceae & Coix lacryma-jobi L. & COXLJ & 2.46
\end{tabular}




\section{Cenchrus echinatus L. $\quad$ CCHEC $\quad 1.67$}

Eleusine indica (L.) Gaertn. $\quad$ ELEIN 17.94

$\begin{array}{llll}\text { Rubiaceae } & \text { Richardia scabra L. } & \text { RCHSC } & 23.81\end{array}$

$\begin{array}{llll}\text { Solanaceae } \quad \text { Solanum grandiflorum Ruiz \& Pav. } & \text { SOLGF } \quad 1.59\end{array}$

$\begin{array}{llll}\text { Turneraceae } & \text { Turnera subulata } \mathrm{Sm} . & \text { TURUL } & 0.71\end{array}$

It is observed in emerged seedlings of the seed bank in the two areas studied, 11 species in common, whose similarity index was estimated at $73.33 \%$. The similarity among species that compose the weed community may be due to the proximity between the areas (Ferreira et al., 2013). However, to perform the descriptive analysis of the data, it is observed that area 01 presented a higher density than area 02 (Tables 3 and 4). Agricultural practices adopted in area 01 might favor higher weed infestation, given that in area 02 , shading and leaf-litter can impede the survival and dispersal of species, particularly pioneers/colonizers. This shows although anthropized, native vegetation may be useful to suppress the advance of invasive species.

Area 01 and 02 exhibited seed density means of 2.254 and 1.058 without $\mathrm{m}^{-2}$, respectively (Table 3). In the first situation (area 01) it highlights the group of dicotyledonous with the means of 2.145 without $\mathrm{m}^{-2}$, which was approximately four times larger than the monocotyledonous in the same area. Among the dicotyledonous, Mollugo verticillata $\mathrm{L}$. and Sida rhombifolia L. highlighted with 936.00 and 504.00 without $\mathrm{m}^{-2}$, respectively. For monocotyledonous, Eleusine indica (L.) Gaertn. came up with 345.30 without $\mathrm{m}^{-2}$. These are the main weed species chosen to create the variability maps of area 01.

This predominance of dicotyledonous species in area 01 may be associated with the selective spectrum of previously used herbicides for weed control in dicotyledonous crops such as soybean. Whereas, the occurrence of Eleusine indica ( $L$. Gaertn. can alert of weed resistance to herbicides such as glyphosate, which has been widely used for pre and post-emergence weed control in this area.

However, in the second situation (area 02), the dicotyledonous (531.20 without $\mathrm{m}^{-2}$ ) and monocotyledonous (504.70 without $\mathrm{m}^{-2}$ ) showed the means with values closest to each other when compared to area 01 (Table 4). 
Table 3. Descriptive statistics of seed density of dicotyledonous weeds (DICO), monocotyledonous (MONO), Mollugo verticillata L. (MOLVE), Sida rhombifolia L. (SIDRH), Eleusine indica (L.) Gaertn. (ELEIN), and total density (DENS) of seeds found in the experimental agricultural field (Area 01)

\begin{tabular}{|c|c|c|c|c|c|c|}
\hline $\begin{array}{c}\text { Species } \\
\text { (without } \mathbf{m}^{-2} \text { ) }\end{array}$ & DICO & MONO & DENS & MOLVE & SIDRH & ELEIN \\
\hline \multicolumn{7}{|c|}{ Experimental agricultural field } \\
\hline Means & 2145.00 & 586.50 & 2254.00 & 936.00 & 504.00 & 345.30 \\
\hline Median & 1548.00 & 489.00 & 2016.00 & 733.00 & 295.00 & 265.00 \\
\hline SD & 1905.00 & 400.50 & 1099.00 & 890.00 & 757.00 & 241.20 \\
\hline $\mathbf{C V}$ & 88.79 & 68.28 & 48.77 & 95.08 & 150.14 & 69,83 \\
\hline DI & 1691.09 & 273.44 & 442.28 & 919.54 & 842.24 & 174.53 \\
\hline $\mathbf{k}$ & 1.27 & 2.15 & 6.19 & 0.94 & 1.88 & 1.92 \\
\hline Min & 285.00 & 122.00 & 631.00 & 61.00 & 20.00 & 265.00 \\
\hline Max & 7556.00 & 1813.00 & 4420.00 & 3177.00 & 3829.00 & 916.00 \\
\hline Asy & 1.79 & 1.53 & 0.46 & 1.03 & 3.99 & 1.21 \\
\hline Curt & 3.14 & 2.78 & -0.80 & 0.28 & 17.67 & 0.78 \\
\hline KS & 0.01 & $>0.15^{*}$ & $>0.15^{*}$ & $0.11^{*}$ & $<0.01$ & $<0.01$ \\
\hline
\end{tabular}

$\mathrm{SD}=$ standard deviation; $\mathrm{CV}=$ Coefficient of variation (\%); ID = dispersion index; $\mathrm{k}=$ parameter $\mathrm{k}$ of the negative binomial distribution; $\mathrm{Min}=$ minimum value; Max = maximum value; Asy $=$ asymmetry coefficient; Curt. $=$ coefficient of kurtosis; $\mathrm{KS}=$ Kolmogorov-Smirnov normality test at 5\% significance level; $(*)$ Variable with normal distribution. 
Table 4. Descriptive statistics of seed density of dicotyledonous weeds (DICO), monocotyledonous (MONO), Richardia scabra L. (RCHSC), Tradescantia fluminensis Vell. (TRAAL), Eleusine indica (L.) Gaertn. (ELEIN), and total density (DENS) of seeds found in the anthropized cerrado (Area 02)

\begin{tabular}{|c|c|c|c|c|c|c|}
\hline $\begin{array}{c}\text { Species } \\
\text { (without } \mathbf{m}^{-2} \text { ) }\end{array}$ & DICO & MONO & DENS & RCHSC & TRAAL & ELEIN \\
\hline \multicolumn{7}{|c|}{ Anthropized cerrado } \\
\hline Means & 531.20 & 504.70 & 1058.00 & 210.10 & 160.20 & 200.10 \\
\hline Median & 366.50 & 367.00 & 876.00 & 183.00 & 61.00 & 183.00 \\
\hline SD & 395.40 & 361.20 & 726.00 & 128.50 & 193.10 & 154.20 \\
\hline $\mathbf{C V}$ & 74.43 & 71.58 & 68.58 & 61.17 & 120.55 & 77.08 \\
\hline DI & 266.12 & 277.18 & 497.88 & 67.61 & 183.95 & 129.20 \\
\hline $\mathbf{k}$ & 2.22 & 1.70 & 2.13 & 3.67 & 1.11 & 1.37 \\
\hline Min & 143.00 & 122.00 & 305.00 & 41.00 & 0.00 & 20.00 \\
\hline $\operatorname{Max}$ & 1690.00 & 1344.00 & 3198.00 & 530.00 & 713.00 & 570.00 \\
\hline Asy & 1.66 & 1.43 & 1.45 & 0.81 & 1.86 & 1.04 \\
\hline Curt & 2.56 & 1.17 & 1.80 & 0.53 & 3.30 & 0.38 \\
\hline KS & $<0.01$ & 0.03 & $<0.01$ & $>0.15^{*}$ & $<0.01$ & $0.06^{*}$ \\
\hline
\end{tabular}

$\mathrm{SD}=$ standard deviation; $\mathrm{CV}=$ Coefficient of variation (\%); ID = dispersion index; $\mathrm{k}=$ parameter $\mathrm{k}$ of the negative binomial distribution; $\mathrm{Min}=$ minimum value; $\mathrm{Max}=$ maximum value; Asy $=$ asymmetry coefficient; Curt. = coefficient of kurtosis; $\mathrm{KS}=$ Kolmogorov-Smirnov normality test at $5 \%$ significance level; $(*)$ Variable with normal distribution.

The species presented positive asymmetric distribution, indicating strong asymmetry coefficients (|Asy|>1) in the two studied areas, except for the total density in area 01 and Richardia scabra $L$. in area 02 which presented moderate asymmetry. $(0.15<\mid$ Asy $\mid<1)$ (Crespo, 2002). The Kolmogorov-Smirnov test indicates the normality of data for monocotyledonous, total density and Mollugo verticillata L. in area 01 . While in area 02 , 
only the species Richardia scabra L. and Eleusine indica (L.) Gaertn. presented the normality of the data.

In both areas studied, the species presented strong spatial variability (CV>60\%) according to the classification by Warrick and Nielsen (1980). Similar results were observed by Ferreira $e t$ al. (2013). This variability is typical of attributes related to the weed seed bank and indicates distribution in spots or patches that can be observed by the dispersion index (DI), with values greater than the unit, as well as by the parameter $\mathrm{k}(\mathrm{k})$, which correlates inversely with the DI. (Cardina et al., 1995; Shiratsuchi et al., 2005).

Seed bank of the species studied showed spatial dependence in area 01, likewise in area 02 (Ferreira et al., 2013). The theoretical, spherical and exponential models expressed better fit to the experimental semivariogram, whereas the dicotyledonous in area 01 fit better to the Gaussian model (Table 5). Comparable results were observed by Siqueira et al. (2016) who obtained the best adjustments for the spherical, exponential and gaussian models. According to the classification of Cambardella et al. (1994), the analyzed species presented strong degree of spatial dependence (DSD), except for dicotyledonous in area 01, which showed moderate DSD.

The species showed different ranges in the studied areas, varying from 14.25 to $56.98 \mathrm{~m}$ in area 01 and among 18 to $34.35 \mathrm{~m}$ in area 02 (Table 5). It was verified the dicotyledonous species presented the highest range values in the two studied areas, which indicates the coverage area of the spatial dependence in which species are distributed, where the highest range value represents a distribution on patches, as observed by Schaffrath et al. (2007).

Ferreira et al. (2013) reported that environmental factors and the lower effectiveness of cultural management, allow the development and dispersal of seeds in cultivated areas, promoting greater infestations of invasive plants in the patches. 


\section{I Macrothink}

Journal of Agricultural Studies ISSN 2166-0379

Table 5. Models and estimated parameters of the experimental semivariograms of seed density of dicotyledonous (DICO), monocotyledonous (MONO), Mollugo verticillata L. (MOLVE), Sida rhombifolia L. (SIDRH), Richardia scabra L. (RCHSC), Tradescantia fluminensis Vell. (TRAAL), Eleusine indica (L.) Gaertn. (ELEIN), and total seed density (DENS) found the experimental agricultural field (area 01), and in the anthropized cerrado (02)

\begin{tabular}{|c|c|c|c|c|c|c|c|}
\hline $\begin{array}{c}\text { Species } \\
\text { (without } \mathbf{m}^{-2} \text { ) }\end{array}$ & Model & $\mathrm{C}_{0}$ & $\mathrm{C}_{0}+\mathrm{C}_{1}$ & $\mathbf{A}_{0}$ & $\begin{array}{c}\text { GDE } \\
(\%)\end{array}$ & $\mathbf{R}^{2}$ & SSR \\
\hline \multicolumn{8}{|c|}{ Experimental agricultural field } \\
\hline DICO & Gaussian & 0.37 & 1.19 & 56.98 & 30.90 & 0.82 & $1.31 \mathrm{E}-01$ \\
\hline MONO & Spherical & 0.02 & 0.44 & 15.87 & 4.57 & 0.78 & $1.70 \mathrm{E}-03$ \\
\hline DENS & Spherical & 0.02 & 0.31 & 25.05 & 5.33 & 0.90 & $1.97 \mathrm{E}-03$ \\
\hline MOLVE & Spherical & 1000.00 & 949490.87 & 27.74 & 0.11 & 0.88 & $5.24 \mathrm{E}+10$ \\
\hline SIDRH & Exponential & 0.00 & 0.97 & 14.25 & 0.10 & 0.46 & $8.20 \mathrm{E}-03$ \\
\hline ELEIN & Exponential & 0.00 & 0.43 & 27.30 & 0.23 & 0.94 & $5.36 \mathrm{E}-04$ \\
\hline \multicolumn{8}{|c|}{ Anthropized cerrado } \\
\hline $\mathrm{DICO}$ & Exponential & 0.09 & 0.53 & 34.35 & 17.11 & 0.86 & $4.03 \mathrm{E}-03$ \\
\hline MONO & Spherical & 0.01 & 0.45 & 18.00 & 2.44 & 0.95 & $5.45 \mathrm{E}-05$ \\
\hline DENS & Spherical & 0.01 & 0.42 & 21.50 & 2.40 & 0.96 & $5.90 \mathrm{E}-04$ \\
\hline RCHSC & Spherical & 0.03 & 0.57 & 19.20 & 5.07 & 0.76 & $5.85 \mathrm{E}-03$ \\
\hline TRAAL & Spherical & 0.23 & 0.98 & 24.09 & 23.64 & 0.84 & $8.11 \mathrm{E}-03$ \\
\hline ELEIN & Spherical & 4257.49 & 25180.00 & 22.00 & 16.91 & 0.82 & $1.35 \mathrm{E}+07$ \\
\hline
\end{tabular}

$\mathrm{C}_{0}=$ nugget effect $; \mathrm{C}_{0}+\mathrm{C} 1=$ threshold $; \mathrm{A}_{0}=$ range $; \mathrm{DSD}=$ Degree of spatial dependence; $\mathrm{R}^{2}=$ Determination coefficient; SSR $=$ Sum of squares of residuals.

In both sampling areas, it was possible to determine spatial distribution maps for dicotyledonous and monocotyledonous (Figures 2 and 3), as also observed by Chiba et al. (2010) and Ferreira et al. (2013). Kriging maps, in the two areas analyzed, represent a spatial 


\section{Macrothink

distribution in spots or patches, confirmed by the dispersion index and the parameter $\mathrm{k}$, as analyzed by Schaffrath et al. (2007) and observed by Siqueira et al. (2016). However, in area 01, Sida rhombifolia L. has a more uniform infestation throughout the landscape.

The aggregate spatial distribution or in patches, allows the management to be carried out locally and the application of variable rate herbicides to be made possible, particularly in area 01 (Schaffrath et al., 2007; Ferreira et al., 2013). Chiba et al. (2010) add that the identification of specific management sites is an auxiliary tool that enables the benefit of the economy of inputs, besides the lower environmental impact.

The application of pre-emergent herbicides with a longer residual period, during four consecutive harvests, can reduce the total soil seed bank, as observed by Amim et al. (2016) in the sugarcane crop. Performing this management in a localized way can increase its efficiency, considering that the use of means values would not adequately represent the distribution of weeds. In the present study, the results express relevance to the chemical control in the experimental fields, whereas in the anthropized cerrado it shows the variations in the spatial distribution in relation to a poorly managed cultivated area.

In area 02 , it observed an aggregation trend of weeds at the edges of the study area (Figure 2), similar to that presented by Chiba et al. (2010). This is probably influenced by weed flora located near the study area, as well as the suppression of arbustive/arboreous species facing more to the center of this area. According to Cardina et al. (1997), when mapping the seed bank of invasive plants in vegetation area is done detailed, it can be used for the prediction of infestation sites in later crops. Furthermore, Leal Filho et al. (2013) report being essential for the study and maintenance of the ecological dynamics of natural areas, helping in the conservation and natural regeneration of disturbed environments.

The use of geostatistical methods and ordinary kriging allowed the mapping of the seed bank and the visualization of aggregate behavior. The use of these tools may favor the adoption of strategies for localized management, particularly in experimental areas or farmer fields. While in native areas it can assist in conservation strategies or natural regeneration in areas anthropized. 

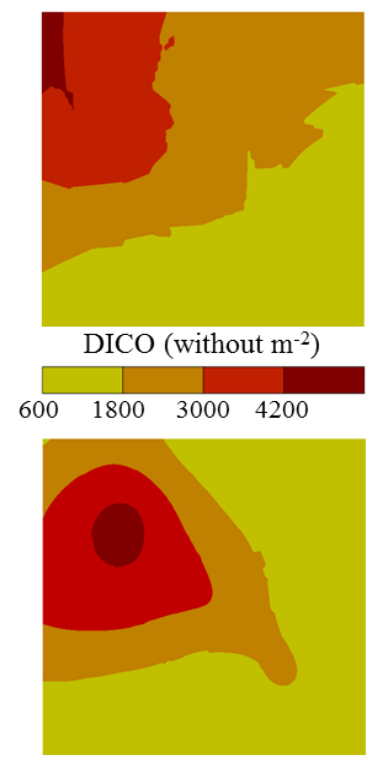

MOLVE (without $\mathrm{m}^{-2}$ )

$61 \quad 961 \quad 1861 \quad 2761$

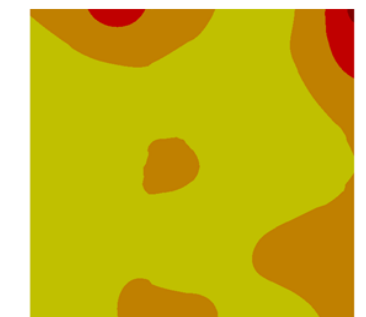

MONO (without $\mathrm{m}^{-2}$ )
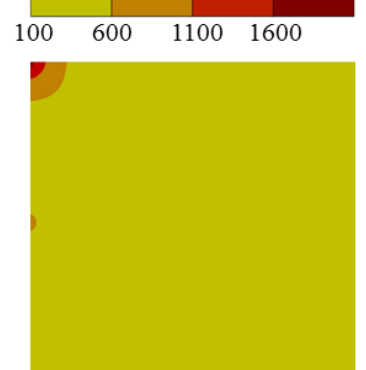

SIDRH (without $\mathrm{m}^{-2}$ )

$22 \quad 1022 \quad 2022 \quad 3022$
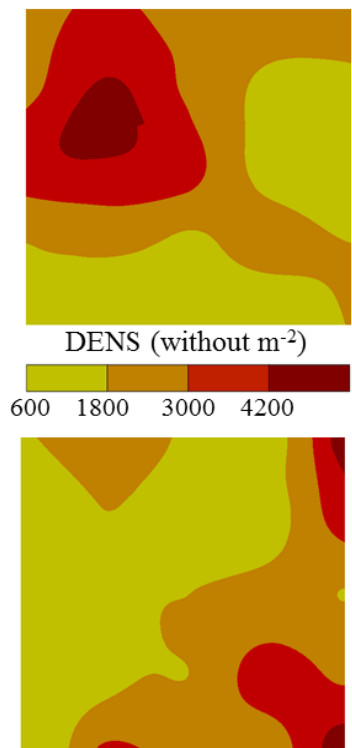

ELEIN (without $\mathrm{m}^{-2}$ )

$83 \quad 291 \quad 499 \quad 707$

Figure 1. Spatial variability maps of seed density of dicotyledonous weeds (DICO), monocotyledonous weeds (MONO), Mollugo verticillata L. (MOLVE), Sida rhombifolia L. (SIDRH), Eleusine indica (L.) Gaertn. (ELEIN), and total density (DENS) of seeds found in the experimental agricultural field (Area 01)
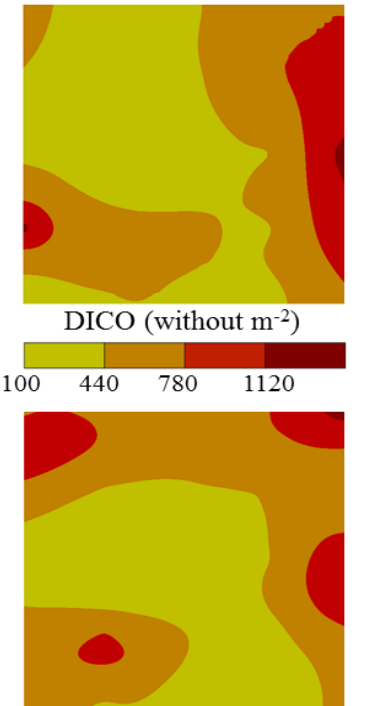

RCHSC (without $\mathrm{m}^{-2}$ )

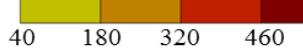

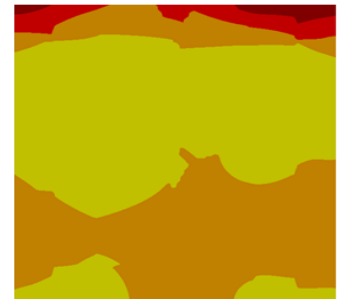

MONO (without $\mathrm{m}^{-2}$ )
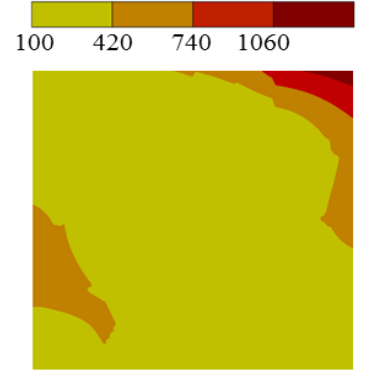

TRAAL (without $\mathrm{m}^{-2}$ )

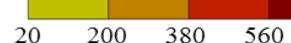

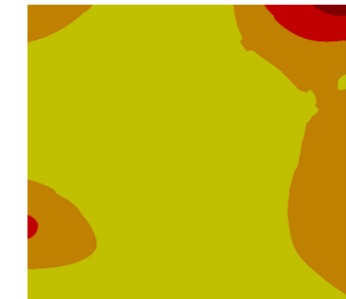
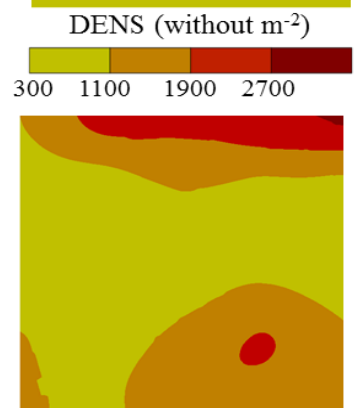

ELEIN (without $\mathrm{m}^{-2}$ )

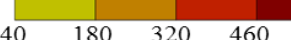

Figure 2. Spatial variability maps of seed density of dicotyledonous (DICO), monocotyledonous (MONO), Richardia scabra L. (RCHSC), Tradescantia fluminensis Vell. (TRAAL), Eleusine indica (L.) Gaertn. (ELEIN), and total density (DENS) of seeds found in the anthropized cerrado area (area 02) 


\section{Conclusion}

The weed seed bank present strong spatial variability as area 01 as for area 02 , which indicates behavior in spots or patches for both dicotyledonous and monocotyledonous plants, especially Mollugo verticillata L. and Eleusine indica (L.) Gaertn. in the experimental field, and for Richardia scabra L. and Eleusine indica (L.) Gaertn. in the anthropized cerrado.

The ordinary kriging technique made it possible to map the weed seed bank and, therefore, it may work as an efficient tool in controlling weeds in agricultural fields, especially in its pre-emergence phase. Furthermore, it can assist in the recovery of native anthropized vegetation.

\section{References}

Amim, R. T., Freitas, S. P., Freitas, I. L. J., \& Scarso, M. F. (2016). Banco de sementes do solo após aplicação de herbicidas pré-emergentes durante quatro safras de cana-de-açúcar. Pesquisa Agropecuária $\quad$ Brasileira. $\quad 51, \quad 1710-1719$. https://doi.org/10.1590/s0100-204x2016001000002

Baio, F. H. R., Pires, L. F., \& Tomquelski, G. (2013). Mapeamento de picão preto resistente aos herbicidas inibidores da ALS na região sul mato-grossense. Bioscience Journal, 29, 59-64.

Bernardi, A. C. C., Naime, J. M., Resende, A. V., Bassoi, L. H., \& Inamasu, R. Y. (2014). Agricultura de Precisão: resultados de um novo olhar. Brasília, DF: Embrapa. P. 596.

Calha, I. M., Sousa, E., \& González-Andújar, J. L. (2014). Infestation maps and spatial stability of main weed species in maize culture. Planta Daninha, 32, 275-282. https://doi.org/10.1590/S0100-83582014000200004

Cambardella, C. A., Moorman, T. B., Novak, J. M., Parkin, T. B., Karlen, D. L., Turco, R. F., \& Konopka, A. E. (1994). Field-scale variability of soil properties in central Iowa soils. Soil Science Society of American Journal, 58, 1501-1511. https://doi.org/10.2136/sssaj1994.03615995005800050033x

Cardina, J., \& Sparrow, D. H. (1996). A comparison of methods to predict weed seedling populations from the soil seedbank. Weed Science, 44, 46-51. https://doi.org/10.1017/S004317450009353X

Cardina, J., Johnson, G. A., \& Sparrow, D. H. (1997). The nature and consequence of weed spatial distribution. Weed Science, 45, 364-373. https://doi.org/10.1017/S0043174500092997

Cardina, J., Sparrow, D. H., \& McCoy, E. L. (1995). Analysis of spatial distribution of common lambsquarters (Chenopodium album) in no-till soybean (Glycine max). Weed Science, 43, 258-268. https://doi.org/10.1017/S0043174500081157

Carmona, R. (1992). Problemática e manejo de bancos de sementes de invasoras em solos agrícolas. Planta Daninha, 10, 5-16. https://doi.org/10.1590/S0100-83581992000100007

Chiba, M. K., Filho, O. G., \& Vieira, S. R. (2010). Variabilidade espacial e temporal de plantas daninhas em Latossolo Vermelho argiloso sob semeadura direta. Acta Scientiarum 
Agronomy, 32, 735-742. https://doi.org/10.4025/actasciagron.v32i4.5445

Christensen, S. D., Ransom, C. V., Edvarchuk, K. A., \& Rasmussen, V. P. (2011). Efficiency and accuracy of wildland weed mapping methods. Invasive Plant Science and Management, 4, 458-465. https://doi.org/10.1614/IPSM-D-11-00015.1

Crespo, A. A. (2002). Estatística fácil. São Paulo: Saraiva. p. 224.

Ferreira, E. A., Fernandez, A. G., Souza, C. P., Felipe, M. A., Santos, J. B., Silva, D. V., \& Guimarães, F. A. R. (2014). Levantamento fitossociológico de plantas daninhas em pastagens degradadas do Médio Vale do Rio Doce, Ceres, 61, 502-510. https://doi.org/10.1590/0034-737X201461040008

Ferreira, E. C. A., Mendonça, C. G., Montanari, R., Possamai, A. C. S., \& Mendonça, C. G. (2013). Espacialização do banco de sementes de plantas daninhas sob diferentes manejos de cana-de-açúcar em Rio Brilhante, Mato Grosso do Sul. Bioscience Journal, 29, 1458-1468. https://doi.org/10.12702/III-SGEA-a26

Franco, B. K. S., Martins, S. V., Faria, P. C. L., \& Ribeiro, G. A. (2012). Densidade e composição florística do banco de sementes de um trecho de floresta estacional semidecidual no campus da Universidade Federal de Viçosa. Revista Árvore, 36, 423-432. https://doi.org/10.1590/S0100-67622012000300004

Gamma Design Software. (2008). GS+: Geostatistics for the environmental Sciences. Gamma Design Software. Michigan: Plainwell.

Jakelaitis, A., Cardoso, I. S., \& Soares, M. P. (2014). Banco de sementes de plantas daninhas em solos cultivados com culturas e pastagens. Global Science and Technology, 7, 63-73. https://doi.org/10.14688/1984-3801/gst.v7n2p63-73

Leal Filho, N., Sena, J. S., \& Santos, G. R. (2013). Variações espaço-temporais no estoque de sementes do solo na floresta amazônica. Acta Amazonica, 43, 305-314. https://doi.org/10.1590/S0044-59672013000300006

Lorenzi, H. (2008). Plantas daninhas do Brasil: terrestre, aquáticas, parasitas e tóxicas. Nova Odessa: Instituto Plantarum. p. 678.

Lousada, L. L., \& Esteves, B. S. (2017). Banco de Sementes de Plantas Daninhas em Áreas de Cana-de-açúcar no Norte Fluminense. Revista FINCA, 4, 49-58.

Monquero, P. A., \& Christffoleti, P. J. (2005). Banco de sementes de plantas daninhas e herbicidas como fator de seleção. Bragantia, 64, 203-209. https://doi.org/10.1590/S0006-87052005000200006

Monquero, P. A., Amaral, L. R., Binha, D. P., Silva, P. V., Silva, A. C., \& Martins, F. R. A. (2008). Mapas de infestação de plantas daninhas em diferentes sistemas de colheita da cana-de-açúcar. Planta Daninha, 26, 47-55.

https://doi.org/10.1590/S0100-83582008000100005

Passos, M. L. V., Zambrzycki, G. C., \& Pereira, R. S. (2016). Balanço hídrico e classificação 
climática para uma determinada região de Chapadinha-MA. Revista Brasileira de Agricultura Irrigada, 10, 758-766. https://doi.org/10.7127/rbai.v10n400402

Santi, A. L., Bona, S. D., Lamego, F. P., Basso, C. J., Eitelwein, M. T., Cherubin, M. R., Kaspary, T. E., ... Gallon, M. (2014). Phytosociological variability of weeds in soybean field. Planta Daninha, 32, 39-49. https://doi.org/10.1590/S0100-83582014000100005

Schaffrath, V. R., Tormena, C. A., Gonçalves, A. C. A., \& Oliveira Junior, R. S. (2007). Variabilidade espacial de plantas daninhas em dois sistemas de manejo de solos. Revista Brasileira Engenharia Agrícola e Ambiental, 11, 53-60. https://doi.org/10.1590/S1415-43662007000100007

Shiratsuchi, L. S., Fontes, J. R. A., \& Resende, A. V. (2005). Correlação da distribuição espacial do banco de sementes de plantas daninhas com a fertilidade dos solos. Planta Daninha, 23, 429-436. https://doi.org/10.1590/S0100-83582005000300006

Silva, M. R. M., Costa, E. A., Marques, L. J. P., \& Corrêa, M. J. P. (2014). Banco de sementes de plantas daninhas em áreas de cultivo de arroz de sequeiro na Pré-Amazônia Maranhense. Revista de Ciências Agrárias Amazonian Journal of Agricultural and Environmental Sciences, 57, 351-357. https://doi.org/10.4322/rca.1297

Siqueira, G. M., Silva, R. A., Aguiar, A. C. F., Costa, M. K. L., \& França e Silva, E. F. (2016). Spatial variability of weeds in an Oxisol under no-tillage system. African Journal of Agricultural Research, 11, 2569-2576. https://doi.org/10.5897/AJAR2016.11120

Soares, A. (2006). Geoestatística para ciências da terra e do ambiente. Lisboa: IST Press. p. 214.

Surfer for windows. Realese 7.0. (1999). Contouring and 3D surface mapping for scientist's engineers. User's guide. New York: Golden Software.

Vieira, S. R. (2000). Geoestatística em estudos de variabilidade espacial do solo. In: Novais, R. F., V. H. Alvares, C. E. G. R. Schaefer. Tópicos em Ciência do Solo. (pp. 1-54).Viçosa: Sociedade Brasileira de Ciência do Solo.

Warrick, A. W., \& Nielsen, D. R. (1980). Spatial variability of soil physical properties in the field. In: Hillel, D. Applications of soil physics (pp. 319-344). New York: Academic. https://doi.org/10.1016/B978-0-12-348580-9.50018-3

Wiles, L. J., Oliver, G. W., York, A. C., Gold, H. J., \& Wilkerson, G. G. (1992). Spatial distribution of broadleaf weeds in North Carolina soybean (Glycine max) fields. Weed Science, 40, 554-557. https://doi.org/10.1017/S0043174500058124

\section{Copyright Disclaimer}

Copyright for this article is retained by the author(s), with first publication rights granted to the journal.

This is an open-access article distributed under the terms and conditions of the Creative Commons Attribution license (http://creativecommons.org/licenses/by/4.0/). 